International Journal of Engineering \& Technology, $7(4.10)(2018) 221-224$
International Journal of Engineering \& Technology
SPC
Website: www.sciencepubco.com/index.php/IJET
Research paper

\title{
A Comparative Study of Factors Influencing Purchasing Decisions at D-Mart and Metro in Vijayawada City.
}

\author{
D. Satish Kumar ${ }^{1 *}$, P. Bindu ${ }^{2}$, D.S. Rao ${ }^{3}$, S. Anusha ${ }^{4}$, J. Srinivas ${ }^{5}$ \\ ${ }^{1,2,}{ }^{41}$ Department of Mathematics, Koneru Lakshmaiah Education Foundation, Vaddeswaram- 522502, India \\ ${ }^{3}$ Business School, Koneru Lakshmaiah Education Foundation, Vaddeswaram- 522502, India \\ ${ }^{5}$ Department of Mathematics, NIT Meghalaya, Shillang-793003, India \\ *Corresponding author E-mail: satish9441321888@gmail.com
}

\begin{abstract}
Corporate retail stores are today the focal points for purchasing decisions of middle and high-income groups in urban India. However, each corporate retail store has its own model of retailing. Storing different varieties of products at same locality, location advantage, selfservicing outlets, window shopping, large scale discount, specialty stores are some of the models retailing stores have adopted. But all these retail models are not being popular among the consumers. Consumer's preferences and choices are varying across different retail models. In this context the present study wants to explore significant difference among corporate retail stores in Vijayawada in consumer preference and choices.
\end{abstract}

Keywords: Retail Shopping, Shopping Behavior, Convenience store, Discount store, Specialty Store, Corporate Retail Stores.

\section{Introduction}

Consumer decision making has long been of interest to researchers. Companies in retail industry are interested in the study of consumer behavior as it makes them familiar with the emerging needs and desires of their current and prospective buyers. To find out what satisfies customers, marketers must examine the main influences on what, where, when and how customers buy goods and services [1]- [6]. By understanding these factors marketers are better able to predict how consumers will respond to marketing strategies. Ultimately, this information helps modern retail malls as well as conventional retail stores to compete more effectively in the marketplace and leading to more satisfied customers [7]- [12].

The present study aims to analyses the differences in shopping behaviors of customers in two leading corporate retail stores in Vijayawada city namely Metro and D-Mart, Andhra Pradesh, India. Of late customers are focusing mainly on quality, quantity, and cost of the products. In this context consumer shopping behavior in respect of retail shopping was analyzed to identify the various factors influencing it. The results of the study reveal that except for average monthly purchasing expenditure, there is no significant differences between Metro and D-Mart in respect of factors that influence purchasing decision.

\section{Objectives of the Study}

The major objectives of the present study are

1. To study the differences in consumer purchasing behavior towards the two corporate retail stores namely D-Mart and Metro in the city of Vijayawada

2. To understand the significant differences in customers habits and choices in their purchase decisions at corporate retail stores in terms of convenience, location advantages, offering discounts and specialty products.

3 To suggest certain interventions to the retailer that could enhance their service quality.

\section{Hypothesis for Study}

$\mathrm{H}_{0}=$ There is no significance difference between D-Mart and Metro with regard features influence ng to shop from a specific retail shop.

$\mathrm{H}_{0}=$ There is no significance difference between D-Mart and Metro with regard in consumer inten -tion of visiting the retail store.

$\mathrm{H}_{0}=$ There is no significance difference between D-Mart and Metro with regard on the duration of time spent on time.

$\mathrm{H}_{0}=$ There is no significance difference be

tween D-Mart and Metro with regard in spend

-ing the amount to purchase the items in these

retail stores.

$\mathrm{H}_{0}=$ There is no significance difference between n D-Mart and Metro with regard features influencing purchasing on constantly visibility of newly launched product.

$\mathrm{H}_{0}=$ There is no significance difference bet ween D-Mart and Metro with regard feature $s$ influencing on most of the times the produ -ct or offer makes you to purchase the produ -ct. $\mathrm{H}_{0}=$ There is no significance difference bet ween D-Mart and Metro on shopping is raisi -ng or decreasing on retail shop.

\section{Research Methodology}

To analyses the consumer behavior in the selected corporate retail stores in Vijayawada two convenient sample of 70 respondents 
from Metro, and 79 respondents from D-Mart were taken respondents were taken, and a structured questionnaire was designed to gather information on six important variables related to consumer behavior from the respondents. The questionnaire was tested for reliability and validity through a pilot study. Information was gathered personally from the consumers when actually they are making purchases. The data gathered was processed and analyzed with descriptive statistics like tables, percentages and bar charts. To test the significance difference between two retail stores in terms of factors influencing there purchasing decision at Independent Samples Mann-Whitney U test was used as the samples were not normally distributed.

\begin{tabular}{|c|c|c|c|c|c|c|c|c|c|c|c|c|c|c|}
\hline $\begin{array}{l}\text { Vari } \\
\text { able }\end{array}$ & $\begin{array}{c}\text { Typ } \\
e\end{array}$ & $\begin{array}{l}\text { La } \\
\text { bel }\end{array}$ & $N$ & $\begin{array}{c}\text { Missi } \\
n g s \\
(\%)\end{array}$ & $\begin{array}{l}M e \\
\text { an }\end{array}$ & $\begin{array}{l}S \\
D\end{array}$ & $S E$ & $\begin{array}{c}\text { Med } \\
\text { ian }\end{array}$ & $\begin{array}{l}\text { Trim } \\
\text { med } \\
\text { Mean }\end{array}$ & $\begin{array}{l}M \\
\text { in }\end{array}$ & $\begin{array}{l}M \\
a x\end{array}$ & $\begin{array}{c}\text { Ran } \\
\text { ge }\end{array}$ & $\begin{array}{l}\text { Skew } \\
\text { ness }\end{array}$ & $\begin{array}{c}\text { Kurt } \\
\text { osis }\end{array}$ \\
\hline Q3 & $\begin{array}{l}\text { inte } \\
\text { ger }\end{array}$ & Q3 & $\begin{array}{l}7 \\
0\end{array}$ & 0 & $\begin{array}{c}2.6 \\
7\end{array}$ & $\begin{array}{l}1 . \\
42\end{array}$ & $\begin{array}{l}0 . \\
17\end{array}$ & 3 & 2.59 & 1 & 5 & 4 & 0.22 & -1.25 \\
\hline Q4 & $\begin{array}{l}\text { inte } \\
\text { ger }\end{array}$ & Q4 & $\begin{array}{l}7 \\
0\end{array}$ & 0 & $\begin{array}{c}2.7 \\
6\end{array}$ & $\begin{array}{l}1 . \\
42\end{array}$ & $\begin{array}{l}0 . \\
17\end{array}$ & 3 & 2.7 & 1 & 5 & 4 & 0.01 & -1.4 \\
\hline Q8 & $\begin{array}{l}\text { inte } \\
\text { ger }\end{array}$ & Q8 & $\begin{array}{l}7 \\
0\end{array}$ & 0 & $\begin{array}{c}1.4 \\
6\end{array}$ & $\begin{array}{l}0 . \\
61\end{array}$ & $\begin{array}{l}0 . \\
07\end{array}$ & 1 & 1.38 & 1 & 3 & 2 & 0.93 & -0.19 \\
\hline Q9 & $\begin{array}{l}\text { inte } \\
\text { ger }\end{array}$ & Q9 & $\begin{array}{l}7 \\
0\end{array}$ & 0 & $\begin{array}{c}3.9 \\
6\end{array}$ & $\begin{array}{l}1 . \\
01\end{array}$ & $\begin{array}{l}0 . \\
12\end{array}$ & 4 & 3.98 & 1 & 5 & 4 & -0.25 & -1.12 \\
\hline Q13 & $\begin{array}{l}\text { inte } \\
\text { ger }\end{array}$ & $\begin{array}{c}\mathrm{Q} 1 \\
3\end{array}$ & $\begin{array}{l}7 \\
0\end{array}$ & 0 & $\begin{array}{c}3.4 \\
3\end{array}$ & $\begin{array}{l}1 . \\
22\end{array}$ & $\begin{array}{c}0 . \\
15\end{array}$ & 3 & 3.45 & 1 & 5 & 4 & -0.05 & -1.32 \\
\hline Q14 & $\begin{array}{l}\text { inte } \\
\text { ger }\end{array}$ & $\begin{array}{c}\text { Q1 } \\
4\end{array}$ & $\begin{array}{l}7 \\
0\end{array}$ & 0 & 2.3 & $\begin{array}{c}0 . \\
75\end{array}$ & $\begin{array}{c}0 . \\
09\end{array}$ & 2 & 2.38 & 1 & 3 & 2 & -0.53 & -1.07 \\
\hline Q15 & $\begin{array}{l}\text { inte } \\
\text { ger }\end{array}$ & $\begin{array}{c}\text { Q1 } \\
5\end{array}$ & $\begin{array}{l}7 \\
0\end{array}$ & 0 & 1.6 & $\begin{array}{c}0 . \\
79\end{array}$ & $\begin{array}{c}0 . \\
09\end{array}$ & 1 & 1.5 & 1 & 3 & 2 & 0.81 & -0.93 \\
\hline
\end{tabular}

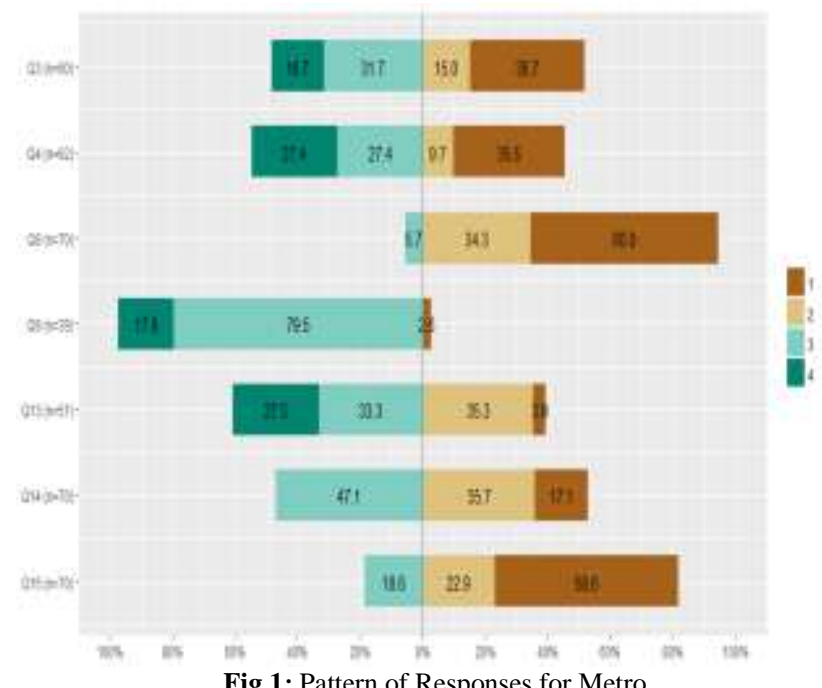

Fig 1: Pattern of Responses for Metro

Table2: Basic descriptive statistics of the sample from D-Mart

\begin{tabular}{|c|c|c|c|c|c|c|c|c|c|c|c|c|c|c|}
\hline $\begin{array}{l}\text { Vari } \\
\text { able }\end{array}$ & Type & $\begin{array}{c}\text { Lab } \\
\text { el }\end{array}$ & $N$ & $\begin{array}{l}\text { TIIJS } \\
\text { ings }\end{array}$ & $\begin{array}{c}\text { Mea } \\
n\end{array}$ & $S D$ & $S E$ & $\begin{array}{l}\text { Med } \\
\text { ian }\end{array}$ & $\begin{array}{l}\mathrm{TII} \\
\mathrm{mm}\end{array}$ & Min & Max & $\begin{array}{c}\text { Ran } \\
\text { ge }\end{array}$ & $\begin{array}{l}\text { Jke } \\
\text { wne }\end{array}$ & Kurtosis \\
\hline Q3 & integer & Q3 & 79 & 0 & 2.6 & 1.4 & 0.2 & 3 & 2.6 & 1 & 5 & 4 & 0.2 & -1.31 \\
\hline Q4 & integer & Q4 & 79 & 0 & 2.6 & 1.4 & 0.2 & 3 & 2.6 & 1 & 5 & 4 & 0.2 & -1.34 \\
\hline Q8 & integer & Q8 & 79 & 0 & 1.6 & 0.7 & 0.1 & 1 & 1.5 & 1 & 4 & 3 & 1.2 & 1.79 \\
\hline Q9 & integer & Q9 & 79 & 0 & 3.5 & 1.2 & 0.1 & 3 & 3.5 & 1 & 5 & 4 & 0 & -1.37 \\
\hline Q13 & integer & Q13 & 79 & 0 & 3.2 & 1.4 & 0.2 & 3 & 3.2 & 1 & 5 & 4 & -0.2 & -1.23 \\
\hline Q14 & integer & Q14 & 79 & 0 & 2.4 & 0.8 & 0.1 & 3 & 2.5 & 1 & 3 & 2 & -0.8 & -1.12 \\
\hline Q15 & integer & Q15 & 79 & 0 & 1.7 & 0.8 & 0.1 & 1 & 1.6 & 1 & 3 & 2 & 0.6 & -1.23 \\
\hline
\end{tabular}

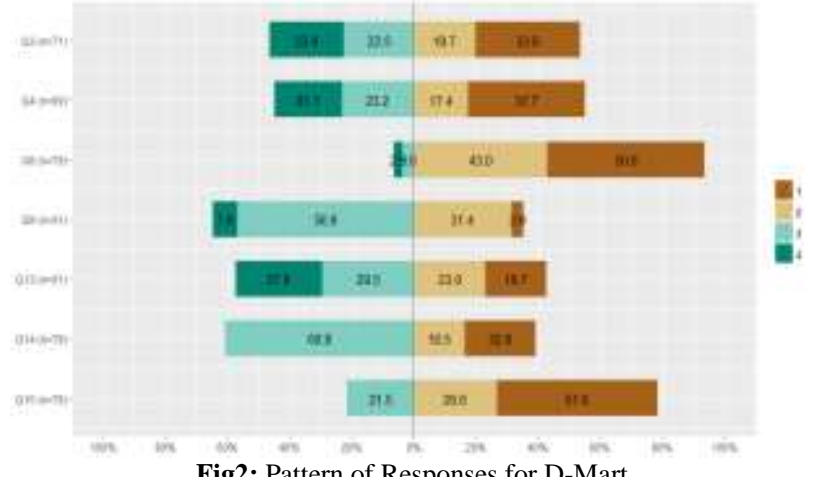

Fig2: Pattern of Responses for D-Mart

\section{Testing of Hypothesis}

\subsection{Hypothesis -I}

$\mathrm{H}_{0}$ : There is no significant difference between D-Mart and Metro with regard to features influencing to shop.

The results of the parametric t-test and non-parametric MannWhitney $U$ test (Table:3) show that the $\mathrm{p}$-value is greater than 0.05 . Thus we may accept the null hypothesis that D-Mart and Metro are similar in features that influence shopping at 5\% level of significance.

Table3: Independent Samples T-Test
\begin{tabular}{|l|l|r|r|l|}
\hline & Test & statistic & df & $\mathrm{p}$ \\
\hline \multirow{2}{*}{ Q3 } & Student's t & -0.168 & \multirow{2}{*}{147} & 0.867 \\
\cline { 2 - 3 } & Mann-Whitney U & 2738 & & 0.917 \\
\hline
\end{tabular}

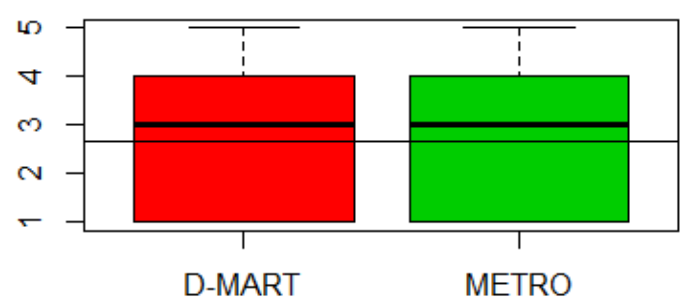

Fig 3: Features influencing to shop

\subsection{Hypothesis - II}

$\mathrm{H}_{0}$ : There is no significance difference between D-Mart and Metro with regard in consumer intention of visiting the retail store.

The results of the parametric t-test and non-parametric MannWhitney $U$ test (Table:4) show that the $p$-value is greater than 0.05 . Thus we may accept the null hypothesis that D-Mart and Metro are similar in features that consumer intention of visiting the retail store at $5 \%$ level of significance

Table: Independent Samples T-Test

\begin{tabular}{|l|l|l|l|l|}
\hline & Test & statistic & df & p \\
\hline \multirow{2}{*}{ Q4 } & Student's t & -0.53 & \multirow{2}{*}{147} & 0.597 \\
\cline { 2 - 3 } \cline { 2 - 2 } & Mann-Whitney U & 2632 & & 0.605 \\
\hline
\end{tabular}

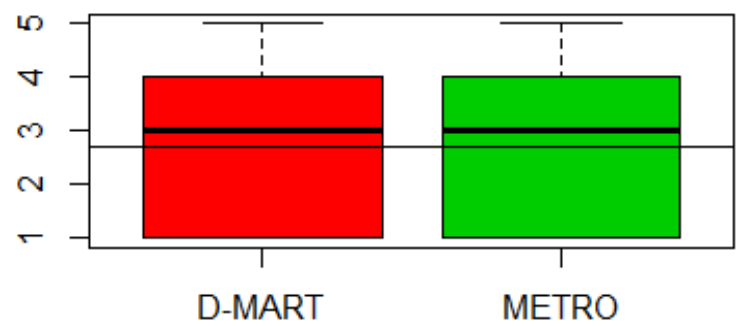

Fig 4: consumer intention of visiting the retail store 


\subsection{Hypothesis -III}

$\mathrm{H}_{0}$ : There is no significance difference between D-Mart and Metro with regard on the duration of time spent on time.

The results of the parametric t-test and non-parametric MannWhitney $U$ test (Table:5) show that the $\mathrm{p}$-value is greater than 0.05 . Thus, we may accept the null hypothesis that D-Mart and Metro are similar in features on the duration of time spent on time at $5 \%$ level of significance

Table5: Independent Samples T-Test

\begin{tabular}{|l|l|r|r|r|}
\hline & Test & statistic & df & p \\
\hline \multirow{2}{*}{ Q8 } & Student's t & 1.17 & \multirow{2}{*}{147} & 0.245 \\
\cline { 2 - 3 } \cline { 2 - 3 } & Mann-Whitney U & 3020 & & 0.271 \\
\hline
\end{tabular}

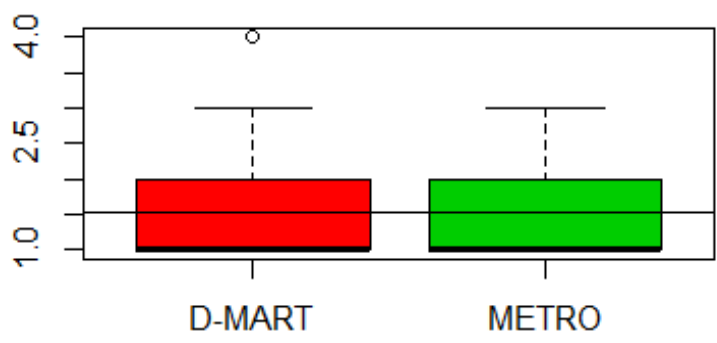

Fig 5: Duration of time spent on time

\subsection{Hypothesis-IV}

$\mathrm{H}_{0}=$ There is no significance difference between D-Mart and Metro with regard in spending the amount to purchase the items in these retail stores.

The results of the parametric t-test and non-parametric MannWhitney $\mathrm{U}$ test (Table:6) show that the $\mathrm{p}$-value is less than 0.05 . Thus, we may reject the null hypothesis that D-Mart and Metro are similar in features on spending the amount to purchase the items at $5 \%$ level of significance

Table6: Independent Samples T-Test

\begin{tabular}{|l|l|r|r|r|}
\hline & Test & statistic & df & \multicolumn{2}{|c|}{ p } \\
\hline \multirow{2}{*}{ Q9 } & Student's t & -2.41 & \multirow{2}{*}{147} & 0.017 \\
\cline { 2 - 3 } \cline { 2 - 3 } & Mann-Whitney U & 2164 & & 0.014 \\
\hline
\end{tabular}

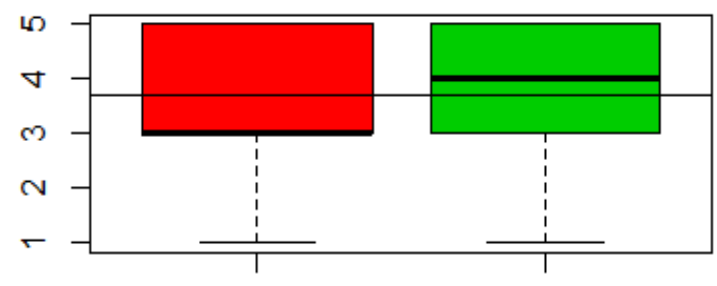

D-MART

METRO

Fig 6: spending the amount to purchase the items

Mean Spending( Out of 5 Categories)

\section{D-MART METRO}

$3.506329 \quad 3.957143$

Median Spending( Out of 5 Categories)

D-MART METRO

34

\subsection{Hypothesis- $V$}

$\mathrm{H}_{0}=$ There is no significance difference between D-Mart and Metro with regard features influencing purchasing on constantly visibility of newly launched product.

The results of the parametric t-test and non-parametric MannWhitney $U$ test (Table:7) show that the $\mathrm{p}$-value is greater than
0.05. Thus we may accept the null hypothesis that D-Mart and Metro are similar in features influencing purchasing on constantly visibility of newly launched product at $5 \%$ level of significance.

Table7: Independent Samples T-Test

\begin{tabular}{|l|l|r|r|l|}
\hline & Test & statistic & df & $p$ \\
\hline \multirow{2}{*}{ Q13 } & Student's t & -1.11 & \multirow{2}{*}{147} & 0.268 \\
\cline { 2 - 3 } \cline { 5 - 5 } & Mann-Whitney U & 2516 & & 0.333 \\
\hline
\end{tabular}

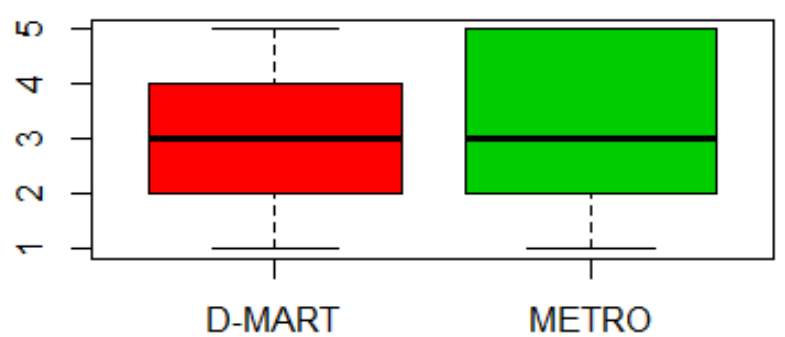

Fig 7: Purchasing on constantly visibility of newly launched product.

\subsection{Hypothesis-VI}

$\mathrm{H}_{0}=$ There is no significance difference between D-Mart and Metro with regard features influencing on most of the times the product or offer makes you to purchase the product.

The results of the parametric t-test and non-parametric MannWhitney $U$ test (Table:8) show that the $\mathrm{p}$-value is greater than 0.05 . Thus we may accept the null hypothesis that D-Mart and Metro are similar in features in flouncing on most of the times the product or offer makes you to purchase the product at $5 \%$ level of significa

-nce

Table8: Independent Samples T-Test

\begin{tabular}{|l|l|r|r|r|}
\hline & Test & statistic & df & $p$ \\
\hline \multirow{2}{*}{ Q14 } & Student's t & 0.61 & \multirow{2}{*}{147} & 0.543 \\
\cline { 2 - 3 } & Mann-Whitney U & 2994 & & 0.335 \\
\hline
\end{tabular}

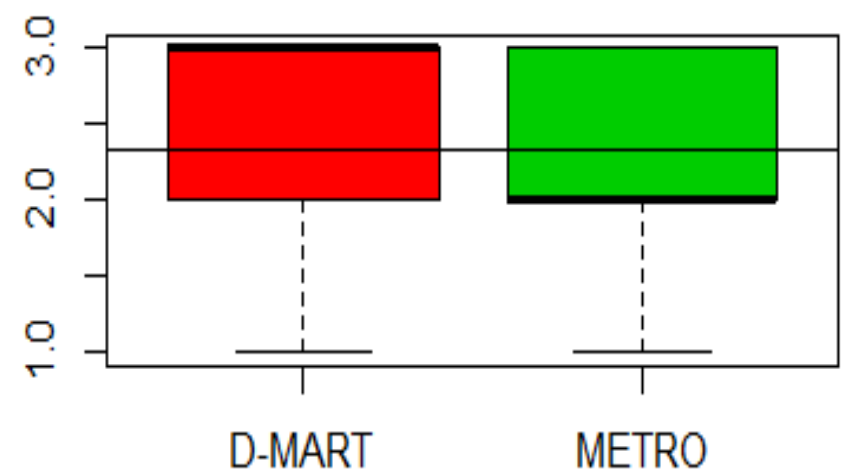

Fig 8: product or offer makes you to purchase the product.

\subsection{Hypothesis - VII}

$\mathrm{H}_{0}=$ There is no significance difference between D-Mart and Metro on shopping is raising or decreasing on retail shop.

The results of the parametric t-test and non-parametric MannWhitney $\mathrm{U}$ test (Table:8) show that the $\mathrm{p}$-value is greater than 0.05 . Thus we may accept the null hypothesis that D-Mart and Metro are similar in features shopping is raising or decreasing on retail shop at $5 \%$ level of significance.

Table9: Independent Samples T-Test

\begin{tabular}{|l|l|c|c|c|}
\hline & Test & statistic & df & P \\
\hline \multirow{2}{*}{ Q15 } & Student's t & 0.735 & \multirow{2}{*}{147} & 0.464 \\
\cline { 2 - 3 } \cline { 2 - 3 } & Mann-Whitney U & 2949 & & 0.438 \\
\hline
\end{tabular}




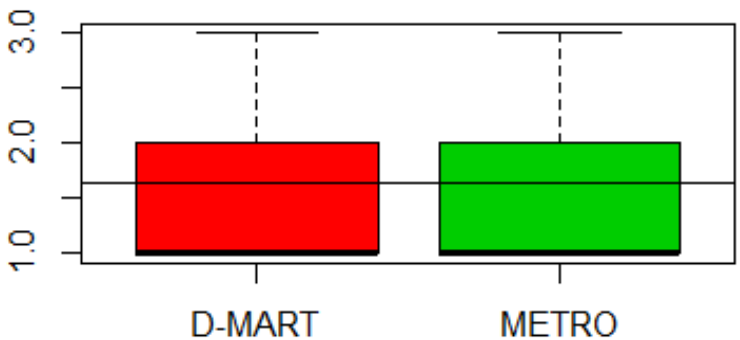

Fig 9: On shopping is raising or decreasing on retail shop

\section{Conclusions of the Study}

Form the testing hypothesis done above the following broad conclusions can be drawn

1. Both D-Mart and Metro attract consumers constantly by enabling visibility of newly launched products.

2. Both D-Mart and Metro attracts customers by offering discounts on purchases.

3. Intentions of the consumer visiting D- Mart and metro are almost similar

4. Metro and D-Mart are similar in features that influence shopping at these stores.

5. The average time spent by a consumer in both D-Mart and Metro is about one and half hrs.

6. There is a significant difference between D-Mart and metro in average spending expenditure by a consumer.

7. Both D-Mart and Metro are witnessing raising trend in Customer spending at their stores

\section{Acknowledgement}

This research was Partially supported by S. Anusha, Asst.Professor, Department .of Mathematics, Koneru Lakshmaiah Education Foundation, Vaddeswaram, A.P, India, To provided valuable time and thoughts to complete this paper. We thank our colleagues Srinivasa Rao. D Professor, Business School, Koneru Lakshmaiah Education Foundation, Vaddeswaram, A.P, India who provided insight and expertise that greatly assisted conclusions of this paper. I thank Bindu. P, Assistant Professor Department of Mathematics, Koneru Lakshmaiah Education Foundation, Vaddeswaram, A.P, India to provided financial support for this work.

\section{References}

[1] Nadira Bessouh, (2016), Effects of Family Roles on the Purchase Decision Process: Empirical Evidence from Algeria, International Journal of Research in Finance and Marketing (IJRFM),Vol. 6 Issue 10 , pp. $135 \sim 150$

[2] Srinivasa Rao. D, Bhoganadam, Syamala. (2016). A study on socio-cultural factors affecting entrepreneurial activity: A conceptual framework. Man in India. 96. 1585-1598, Arpan, K. (2015). Business Fundas. Brand personality dimensions. http://businessfundas.com/2011/brand-personality-dimensions/

[3] Perreau, F. (2014), The Consumer Factor. The Consumer Buying Decision Process. http:// theconsumerfactor.com/en/5-stagesconsumer-buying-decisionprocess/ Accessed on 29 December 2014.

[4] Mark D Griffiths, Lisa K Gundry, \& Jill R Kickul. (2013). The socio-political and cultural determinants of social entrepreneurial activity. Journal of small Business and Enterprise Development, 20 (2), 341-357.

[5] Akpor-Robaro, \& Masoje Oghenerobaro Mamuzo. (2012). The imapct of socio cultural environment on Entrepreneurial emergence: A theoretical analysis on Nigerian society. European journal of Business and Management, 4 (16), 172-182.
[6] Watney, T., \& Brennan, L. (2011). Behavioral change starts in the family: the role of family communication and implications for social marketing. Journal of Nonprofit \& Public Sector marketing, 13(4), 367-386

[7] Kardes, F. Cline, T. Cronley, M. (2011). Consumer behavior: Science and Practice. South-Western Cengage Learning.

[8] Aaker, J. (1997). Dimensions of brand personality. Journal of Marketing Research. Volume 34.347-356.

[9] Kotler, P. \& Armstrong, G. (2009). Principles of Marketing. Pearson Education. Thirteenth Edition. New Jersey,

[10] Folke ölander, John ThØgersen.,(1995), Understanding of consumer behaviour as a prerequisite for environmental protection , Journal of Consumer Policy, Volume 18, Issue 4, 345-385 